\title{
PEMANFAATAN LABORATORIUM IPA DAN BAHASA PADA MADRASAH ALIYAH SWASTA
}

\author{
Umul Hidayati \\ Peneliti Puslitbang Pendidikan Agama dan Keagamaan \\ Badan Litbang dan Diklat Kementerian Agama Republik Indonesia \\ Jl. MH Thamrin No. 06 Jakarta Pusat \\ hidayatikuncoro@yahoo.com
}

Abstract

In an effort to increase the quality of education in Madrasah, the government (the Minister of Religious Affairs through Islamic Education General Director), since 1995, has performed a supportive program in science laboratories by providing for needs in several MTsN (Islamic public junior high schools). In the year 1998, support was given to 35 MAN (Islamic public senior high schools) and in the year 2005 to several considerably superior MA (Islamic private high schools). In the year 2010 support was given to 400 private MA in 19 provinces. In the same year, support was given to $100 \mathrm{MA}$ laboratory facilities in 11 provinces. The massive amount of support has not yet been able to be used optimally in order to increase the quality of education by the Madrasah(s) because of many obstacles such as: the low quantity of human resources (teacher and laboratory staff), the fact that several MA do not possess a laboratory building (Science and Linguistic major), and the fact that science and linguistic majors do not exist in several Madrasah. On the other hand, distribution of funds also experienced many difficulties. The result of the research of the Center of Research and Development Islamic Education and Religion in the year 2012 entitled the "Use of the laboratory facilities in Madrasah (the study of the well-funded science and linguistic laboratory Madrasah Aliyah)" indicates that the use of laboratory facilities has not yet been maximized by the Madrasah and support for implementation has experienced many difficulties.

Keyword: use, laboratory, Madrasah Aliyah Swasta

\section{Abstrak}

Dalam upaya meningkatkan mutu pendidikan di Madrasah, pemerintah (Kementerian Agama melalui Dirjen Pendis) mengeluarkan program bantuan sarana laboratorium IPA yang dimulai tahun 1995 dengan memberikan bantuan pada beberapa MTsN. Pada tahun 1998, bantuan diberikan kepada 35 MAN dan pada tahun 2005 bantuan diberikan kepada beberapa MA Unggulan. Pada tahun 2010 bantuan diberikan kepada 400 MA swasta di 19 propinsi. Pada tahun yang sama, juga diberikan bantuan sarana laboratorium bahasa pada 100 MA swasta di 11 propinsi. Besarnya bantuan yang diberikan selama ini ternyata belum dapat dimanfaatkan madrasah secara maksimal untuk meningkatkan mutu pendidikan karena terkendala oleh banyak hal antara lain terbatasnya SDM (pendidik dan tenaga laboran), sebagian MA belum memiliki gedung laboratorium (IPA dan bahasa); tidak memiliki jurusan IPA dan bahasa. Di samping itu, dalam pelaksanaannya pemberian bantuan ini juga masih menuai banyak masalah. Hasil penelitian Puslitbang Pendidikan Agama dan Keagamaan tahun 2012 berjudul Pemanfaatan Sarana Laboratorium Pada Pendidikan di Madrasah (Studi Pada Madrasah Aliyah Penerima Bantuan Laboratorium IPA dan Bahasa)"menunjukkan bahwa pemanfaatan sarana laboratorium oleh madrasah belum maksimal dan pemberian bantuan tersebut dalam pelaksanaannya banyak menuai masalah.

Kata Kunci: Pemanfaatan, Laboratorium, Madrasah Aliyah Swasta

Naskah diterima 11 Januari 2013. Revisi pertama, 21 Februari 2013. Revisi kedua, 7 Maret 2013 dan revisi terahir 02 April 2013. 


\section{PENDAHULUAN}

Ilmu Pengetahuan Alam (IPA), merupakan salah satu mata pelajaran yang tidak hanya diajarkan melalui teori, tetapi juga memerlukan praktek. Oleh karena itu untuk mengajarkan IPA, hendaknya madrasah (MA) mempunyai Laboratorium. Dengan adanya Laboratorium, diharapkan pembelajaran IPA dapat dilaksanakan dengan baik sebagaimana seharusnya. Begitu juga dengan pelajaran bahasa, keberadaan laboratorium juga menjadi sarana penting. Pembelajaran bahasa (terutama bahasa asing) yang dilakukan dengan menggunakan bantuan sarana laboratorium, lebih mempermudah bagi peserta didik dalam memahami, mengerti dan mempraktekkan bahasa asing tersebut dalam kehidupan sehari-hari.

Dalam kenyataan, tidak semua sekolah (MA) memiliki Laboratorium. Hal ini menjadi kendala bagi sekolah yang bersangkutan. Karena untuk bisa maju, sekolah harus bisa menghasilkan lulusan yang berkompeten bukan hanya secara teori, tetapi juga praktek. Untuk dapat mewujudkan hal tersebut, salah satu unsur pendukung penting dalam praktek adalah tersedianya laboratorium, sehingga pelaksanaan pembelajaran materi pelajaran yang membutuhkan bantuan laboratorium seperti materi pelajaran IPA dan bahasa dapat dilaksanakan secara maksimal dan hasil yang diperolehnyapun juga maksimal.

Dalam upaya meningkatkan mutu pendidikan di Madrasah, pemerintah (Kementerian Agama melalui Dirjen Pendis) telah melakukan berbagai upaya salah satunya melalui pemberian bantuan sarana laboratorium IPA dan bahasa. Program bantuan ini merupakan kerjasama Kemenag dengan Islamic Development Bank (IDB) sebagai Program Penguatan Sains dan Teknologi (STEP-1) yang diberikan pada beberapa MA Unggulan seperti MA Model dan MA unggul non model di berbagai daerah. Program ini telah dimulai tahun 1995 dengan memberikan bantuan sarana laboratorium pada beberapa MTsN. Pada tahun 1998, bantuan perangkat laboratorium IPA tersebut diberikan kepada 35 MAN. Sedangkan pada tahun 2005, juga melalui kerjasama dengan IDB dalam Program STEP-2, bantuan diberikan kepada beberapa MA Unggulan.

Pada tahun 2010, bantuan laboratorium IPA diberikan kepada 400 MA swasta yang ada di 19 Propinsi yaitu Propinsi Sumut, Riau, Sumsel, Bengkulu, Jambi, Lampung, DKI Jakarta, Banten, Jabar, Jateng, Jatim, Kalsel, Kalbar, Kaltim, NTB, Bali, Sulsel, Sulut dan Gorontalo ${ }^{1}$ dan bantuan laboratorium bahasa diberikan kepada 100 MA Swasta yang ada di 11 propinsi yaitu Sumbar, Riau, Sumsel, Lampung, DKI Jakarta, Banten, Jabar, Jateng, Jatim, Kalsel, Kaltim dan NTB. ${ }^{2}$

Banyaknya bantuan yang digulirkan oleh pemerintah dalam beberapa tahun terakhir ini, dengan harapan madrasah mampu memanfaatkannya untuk menunjang kelancaran pelaksanaan pembelajaran dan mendukung pencapaian efektifitas, efisiensi dan sekaligus kualitas pembelajaran mata pelajaran IPA dan bahasa, sehingga mampu meningkatkan hasil belajar di madrasah, yang pada akhirnya mampu meningkatkan mutu dan prestasi madrasah.

Bagaimana program bantuan tersebut dilaksanakan dan sejauhmana pemanfaatan bantuan sarana laboratorium tersebut oleh madrasah, Puslitbang Pendidikan Agama dan Keagamaan tahun 2012 telah melakukan penelitian berjudul "Pemanfaatan Sarana Laboratorium Pada Pendidikan di Madrasah (Studi Pada Madrasah Aliyah Penerima Bantuan Laboratorium IPA dan Bahasa)", untuk melihat bagaimana pelaksanaan pemberian bantuan dan pemanfaatannya sebagai sarana dalam menunjang kelancaran pelaksanaan pembelajaran di Madrasah Aliyah (MA). Penelitian ini perlu dilakukan, karena pemberian bantuan telah dilaksanakan berulangkali yang dimulai tahun 2005 dan hingga sekarang masih terus berlangsung, untuk melihat apakah pemberian bantuan ini terdapat kendala/masalah dalam pelaksanaannya

${ }^{1}$ Keputusan Dirjen Pendis Nomor: DJ.I/744.A/2010, tertanggal 28 Oktober 2010, Tentang Penetapan Penerima Bantuan Alat Laboratorium IPA Terpadu MA.

${ }^{2}$ Keputusan Dirjen Pendis Nomor: DJ.I/1473.N/2011, tertanggal 28 Oktober 2010, Tentang Penetapan Penerima Bantuan Alat Laboratorium Bahasa Tahun Anggaran 2010. 
baik pada tingkat pelaksanana/pemilik program (Kemenag melalui Dirjen Pendis) maupun pada tingkat sasaran/penerima bantuan.

\section{Permasalahan Penelitian}

Dari uraian latar belakang masalah tersebut, permasalahan penelitian ini adalah bagaimana pelaksanaan pemberian bantuan sarana laboratorium IPA dan bahasa dan bagaimana pemanfaatannya dalam menunjang kelancara pelaksanaan proses pembelajaran IPA dan bahasa di Madrasah Aliyah penerima bantuan, serta bagaimana kendala yang dihadapi dalam pemanfaatan bantuan sarana laboratorium IPA dan bahasa dan dalam pelaksanaan pemberian bantuan tersebut.

\section{Tujuan}

Dari rumusan masalah tersebut, tujuan penelitian ini untuk mengetahui:

1. Pemanfaatan sarana lanoratorium IPA dan bahasa dalam pelaksanaan pembelajaran IPA dan bahasa pada Madrasah Aliyah, dilihat dari:

a. Proses pemanfaatannya, meliputi: persiapan, pelaksaan dan penilaian hasil pemanfaatan.

b. Cara/teknis pemanfaatannya, meliputi pemakaian, perawatan, penyimpanan, penyediaan SDM dan kebijakan dalam pemanfaatan sarana laboratorium IPA dan bahasa.

c. Kegiatan pemanfaatan meliputi jenis, frekuensi dan jadwal kegiatan pembelajaran praktikum IPA dan bahasa.

2. Kendala yang dihadapi MA dalam pemanfaatan sarana laboratorium IPA dan bahasa, dilihat dari:

a. Ketersediaan, ketercukupan dan kondisi sarana laboratorium yang meliputi bahan, alat dan gedung. b. Ketersediaan, ketercukupan dan kondisi pendidik/guru mata pelajaran IPA dan bahasa serta tenaga laboran dilihat dari jumlah, kualifikasi dan kompetensinya.

c. Ketersediaan dan ketercukupan pembiayaan

3. Pelaksanaan pemberian bantuan dan kendala yang dihadapi dalam pelaksanaan pemberian bantuan sarana laboratorium IPA dan bahasa.

\section{KERANGKA KONSEPTUAL}

\section{Pengertian Pemanfaatan}

"Pemanfaatan" berarti proses memanfaatkan sesuatu, dengan cara tertentu dan melalui kegiatan tertentu, agar dapat memberi faedah, kegunaan, keuntungan. Menurut $\mathrm{AECT}^{3}$ pemanfaatan sumber belajar bertujuan untuk mengusahakan agar peserta didik dapat berinteraksi dengan berbagai sumber belajar dalam komponen sistem pembelajaran. Terkait dengan pemanfaatan laboratorium, bertujuan agar peserta didik dapat berinteraksi dengan laboratorium dan perangkat sarana yang ada di dalamnya. Dalam pemanfaatan meliputi kegiatan sebelum, selama dan sesudah. Kegiatan sebelum meliputi kegiatan persiapan (pendidik menyiapkan diri, menyiapkan peserta didik, lingkungan, peralatan, bahan dna tempat); kegiatan selama meliputi kegiatan praktikum yang dilakukan di laboratorium; dan kegiatan sesudah yaitu kegiatan penilaian dengan memberikan tes dan tugas kepada peserta didik untuk melakukan evaluasi hasil belajar praktikum. Menurut Sadiman ${ }^{4}$ bahwa agar kegiatan pemanfaatan berjalan efektif dan efisien, ada tiga tahapan kegiatan yang harus diikuti yaitu: 1) persiapan, dengan langkah-langkah pengaturan jadwal, penyusunan rancangan keg-

${ }^{3}$ Yusuf Hadi Miarso, 1994, Definisi Teknologi Pendidikan: Satuan Tugas Definisi dan Teknologi AECT, Jakarta: CV. Rajawali, h. 194.

${ }^{4}$ Arief F. Sadiman dkk, 1990, Media Pendidikan: Pengertian Pengembangan dan Pemanfaatannya, Jakarta: CV. Rajawali, h. 197. 
iatan, pemeriksaan dan mempersiapkan alat dan bahan; 2) pelaksanaan kegiatan; 3) kegiatan tindak lanjut untuk menjajaki apa tujuan telah tercapai dan untuk memantapkan pemahaman materi.

Dari pengertian ini, yang dimaksud dengan pemanfaatan laboratorium adalah suatu proses dalam memanfaatkan sarana laboratorium dengan menggunakan teknik atau cara tertentu dalam menunjang kegiatan pembelajaran, guna mencapai tujuan pembelajaran yang diharapkan. Ada empat kata kunci dalam pemanfaatan yaitu proses, cara/teknis, perbuatan/ aktivitas pemanfaatan dan sumber/ alat belajar berupa sarana laboratorium.

Proses adalah jalannya suatu peristiwa/ kegiatan dari awal sampai akhir ${ }^{5}$ Dalam kaitannya dengan pemanfaatan laboratorium, proses berarti rangkaian kegiatan yang dilaksanakan pendidik dan peserta didik dalam pemanfaatan laboratorium, yaitu kegiatan pembelajaran praktikum (IPA dan bahasa) dengan memanfaatkan sumber belajar berupa sarana laboratorium. Rangkaian kegiatannya mencakup persiapan, pelaksanaan dan evaluasi/penilaian. Sedangkan cara atau teknis pelaksanaan dalam pemanfaatan laboratorium meliputi strategi pemanfaatan (pemakaian, perawatan, penyimpanan sarana laboratorium, tempat, ruangan maupun gedung); penyediaan SDM (pendidik dan tenaga laboran) dan kebijakan madrasah dalam pemanfaatan laboratorium. Adapun perbuatan/aktivitas memanfaatkan sarana laboratorium adalah bentuk kegiatan yang dilakukan dalam pemanfaatan laboratorium yang meliputi jenis-jenis/bentuk kegiatan praktikum yang dilakukan, frekuensi kegiatan, waktu pelaksanaan kegiatan.

Berdasar pengertian tersebut, hal-hal yang digali dalam penelitian terkait dengan pemanfaatan laboratorium meliputi: 1). Proses (persiapan, pelaksanaan dan penilaian); 2). Cara atau teknis pemanfaatan (pemakaian, perawatan dan penyimpanan sanara labora-

${ }^{5}$ Barbara Seels dan Rita C. Richy, 1994, Teknologi Pembelajaran, Jakarta: Universitas Negeri Jakarta Press, h. 12 torium), penyediaan SDM (pendidik dan tenaga laboran) dan kebijakan madrasah dalam pemanfaatan laboratorium; 3). Kegiatan yang dilakukan dalam pemanfaatan laboratorium (jenis/bentuk kegiatan, frekuensi kegiatan, kualitas kegiatan, waktu pelaksanaan kegiatan).

\section{Peran dan Fungsi Laboratorium}

Disamping manfaat, laboratorium juga memiliki peran dan fungsi. Dalam arti sempit, fungsi laboratorium adalah sebagai tempat berlangsungnya kegiatan pembelajaran secara praktek yang memerlukan peralatan khusus yang tidak mudah dihadirkan di ruang kelas. Secara umum fungsi laboratorium adalah sebagai tempat dilakukannya percobaan, sebagai tempat penunjang kegiatan kelas, sebagai tempat display/pameran, sebagai tempat koleksi sejumlah species langka dan sebagai tempat museum kecil. ${ }^{6}$

Di dalam pembelajaran IPA, dikenal tiga jenis laboratorium yaitu laboratorium fisika, kimia dan biologi, yang masing-masing memiliki fungsi yang hampir sama. Laboratorium fisika, berfungsi sebagai tempat berlangsungnya kegiatan pembelajaran fisika secara praktek yang membutuhkan peralatan khusus. Laboratorium kimia, berfungsi sebagai tempat berlangsungnya kegiatan pembelajaran kimia secara praktek yang membutuhkan peralatan khusus. Laboratorium biologi, berfungsi sebagai tempat berlangsungnya kegiatan pembelajaran biologi secara praktek yang membutuhkan peralatan khusus. ${ }^{7}$ Dalam pembelajaran sains, laboratorium berperan sebagai tempat kegiatan penunjang dari kegiatan kelas. Menurut Amien dalam Tarmizi ${ }^{8}$ fungsi laboratorium adalah sebagai:

${ }^{6}$ Apis Indika, http://bioonline.wordpress. com/2011/06/07/pengertian-laboratorium/, diunduh tanggal 3 Januari 2012

${ }^{7}$ Republik Indonesia, Permendiknas No. 40 Tahun 2008 Tentang "Standar Sarana dan Prasarana Untuk Sekolah Menengah Kejuruan/Madrasah Aliyah Kejuruan (SMK/MAK)".

${ }^{8}$ http://baim87-bio.blogspot.com/2011/05/pemanfaatan-laboratorium-dalam-belajar. html, diunduh tanggal 3 Januari 2012. 
a. Tempat untuk menguatkan/memberi kepastian keterangan (informasi).

b. Tempat untuk mentukan hubungan sebab-akibat (causalitas).

c. Tempat untuk membuktikan benar tidaknya faktor-faktor atau fenomena-fenomena tertentu, untuk dapat dijadikan hukum atau dalil.

d. Tempat untuk mempraktekkan sesuatu yang diketahui.

e. Tempat untuk mengembangkan keterampilan.

f. Tempat untuk memberikan latihan

g. Tempat untuk membentuk siswa belajar menggunakan metode ilmiah dalam memecahkan problem.

h. Tempat melanjutkan/melaksanakan penelitian perorangan (individual research).

Sedangkan menurut Subiyarto, ${ }^{9}$ fungsi laboratorium sebagai tempat untuk:

a. Munculnya berbagai masalah dan sekaligus memecahkan berbagai masalah tersebut baik yang dijumpai di kelas, di laboratorium maupun di mana saja.

b. Melakukan kegiatan ilmiah seperti eksperimen, penelitian, percobaan dan penyelidikan.

c. Memberi peluang pada siswa untuk bekerja dengan menggunakan alat-alat dan bahan-bahan tertentu.

d. Memberi kesempatan bagi siswa untuk dapat bekerjasama dengan kawan dan meningkatkan gairah untuk mengungkap dan menemukan sesuatu yang tidak diketahui.

e. Meningkatkan kesadaran siswa tentang peranan ilmuan di masyarakat

f. Merintis perkembangan sikap, kebiasaan dan keterampilan siswa yang bermanfa-

${ }^{9}$ Subiyanto, 1990, Strategi Belajar Mengajar Ilmu Pengetahuan Alam/IPA, Malang: IKIP Malang, h. 83. at bagi perkembangan pikiran dan wawasannya.

Dari pengertian ini dapat disimpulkan, laboratorium tidak hanya sekedar sebagai tempat melakukan kegiatan bersifat ilmiah seperti penelitian, percobaan, eksperimen, pengujian $\mathrm{dsb}$, tetapi juga memiliki fungsi lain yang lebih luas. Terkait dengan penelitian ini, fungsi laboratorium yang dilihat juga diperluas mencakup fungsi-fungsi lainnya sebagaimana diuraikan.

\section{Pengertian Laboratorium}

Laboratorium, merupakan sarana pembelajaran yang memiliki peranan penting menunjang suksesnya pembelajaran. Beberapa materi pelajaran yang membutuhkan pembuktian, penelitian dan percobaan, tidak dapat dipahami sekedar belajar teori, tetapi membutuhkan sarana laboratorium sebagai wahana praktikum. Dalam pengertian terbatas, laboratorium adalah suatu ruangan dimana penelitian dan percobaan dilakukan.

Menurut Kertiasa, laboratorium adalah tempat untuk mengadakan percobaan atau penyelidikan dalam bidang ilmu fisika, kimia, biologi. Tempat ini dapat berupa ruang tertutup, kamar, ruang terbuka seperti kebun dsb. 10 Sedangkan menurut Suharsimi, laboratorium adalah tempat melakukan percobaan, sehingga apa yang diterima siswa dari materi pelajaran IPA melalui kegiatan di kelas dapat dibuktikan. ${ }^{11}$ Definisi ini memberi pengertian bahwa laboratorium merupakan tempat untuk membuktikan suatu materi yang didapat di kelas. Sementara Safritz, memberikan definisi bahwa laboratorium adalah ruang pembelajaran khusus yang dirancang dan dilengkapi dengan alat-alat khusus yang memungkinkan partisipasi siswa dalam aktivitas belajar melalui percobaan ilmiah. ${ }^{12}$ Menurut Soewito, bahwa laboratorium adalah suatu ruangan

${ }^{10}$ Nyoman Kertiasa, 2006, Laboratorium Sekolah dan Pengelolaannya, Jakarta: Pudak Scientivic, h.1

${ }^{11}$ Suharsimi Arikunto, 1987, Pengelolaan Materiil, Jakarta: Prima karya, h.65

${ }^{12}$ Jay M. Safritz, 1988, The Facts on File Dictionary of Education, New York: Facts on File, h.3. 
yang dilengkapi dengan berbagai peralatan khusus yang digunakan untuk melakukan percobaan ilmiah. ${ }^{13}$ Menurut Lubis, laboratorium merupakan ruangan dengan berbagai macam peralatan dimana dilakukan kegiatan penelitian dan percobaan sehingga mendapatkan penemuan baru atau pembuktian teori yang telah dipelajari. ${ }^{14}$ Menurut Depdikbud, laboratorium adalah suatu tempat yang dilengkapi dengan seperangkat peralatan, dimana percobaan danpenyelidikan dilakukan. ${ }^{15}$ Laboratorium bias juga diartikan sebagai tempat kerja seorang ilmuan untuk melangsungkan penelitian ilmiah atau menjalankan percobaan bidang studi IPA. ${ }^{16}$

Dari beberapa pengertian tersebut dapat disimpulkan, laboratorium adalah suatu tempat atau ruangan tertentu yang dilengkapi dengan peralatan dan infrastruktur laboratorium yang lengkap, yang difungsikan untuk tempat bekerja, pembelajaran praktikum dan melakukan berbagai kegiatan ilmiah seperti penelitian, percobaan, eksperimen, pengujian atau tempat untuk membuktikan/mempraktekkan teori-teori yang telah dipelajari di kelas. Berdasarkan jenisnya, maka laboratorium yang dilihat dalam penelitian ini adalah laboratorium yang digunakan sebagai sarana pembelajaran IPA dan bahasa jenjang SLTA (MA) yang meliputi laboratorium fisika, kimia, biologi dan laboratorium bahasa.

\section{METODOLOGI PENELITIAN}

Penelitian ini dilakukan dengan menggunakan metode survey. Sedangkan pendekatannya adalah kuantitatif. Penelitian dilakukan pada MA swasta yang memperoleh bantuan sarana laboratorium IPA dan bahasa

${ }^{13}$ Soewito Soekoro, 1987, Kamus Pintar Ilmu Pengetahuan Alam/SAINS, Jakarta: Citra Wacana Mitra pelajar, h.88

${ }^{14}$ Muhsin Lubis dkk, 1993, Pengelolaan Laboratorium Ilmu Pengetahuan Alam, Jakarta: Universitas Terbuka, h.37 ${ }^{15}$ Depdikbud, 1988, Pengelolaan laboratorium dan Manual Alat IPA, Jakarta: CV. Arga Karya, h.7

${ }^{16}$ Baim, http://baim87-bio-blogstpot.com/2011/05/ pemanfaatan-laborato rium-dalam-belajar-html, diunduh tanggal 3 Januari 2012. di 9 propinsi yaitu Propinsi Sumsel, Lampung, Banten, DKI Jakarta, Jabar, Jateng, Jatim, Sulsel dan NTB. Adapun waktu pelaksanaannya sejak dari persiapan sampai penyusunan laporan, dilaksanakan selama 8 bulan, dimulai bulan Pebruari hingga September 2012.

Populasi penelitian ini adalah seluruh MA yang ada di 20 propinsi. Sedangkan populasi target/sasaran penelitiannya adalah seluruh MA swasta penerima bantuan sarana laboratorium IPA dan bahasa tahun 2010 yang ada di 20 propinsi tersebut, yang berjumlah $500 \mathrm{MA}$ swasta (400 MA penerima bantuan laboratorium IPA di 19 propinsi dan 100 MA penerima bantuan laboratorium bahasa di 11 propinsi). Adanya beberapa keterbatasan dalam penelitian seperti keterbatasan SDM/tenaga peneliti, keterbatasan waktu dan biaya, sehingga penelitian difokuskan hanya di 9 propinsi yaitu Sumut, Riau, Sumbar, Jambi, Bengkulu, Sumsel, Lampung, Banten, DKI, Jabar, Jateng, Jatim, Kalsel, Kalbar, Kaltim dan Bali, dengan jumlah MA sasaran menjadi 460 MA (370 MA penerima bantuan sarana laboratorium IPA dan $90 \mathrm{MA}$ penerima bantuan sarana laboratorium bahasa).

Penentuan besaran sampel dalam penelitian ini dilakukan dengan menggunakan rumus Slovin dengan Margin of Error (MoE) 5\% dan tingkat kepercayaan 95\%. Dengan menggunakan rumus tersebut, dari 460 MA penerima bantuan sarana laboratorium IPA dan bahasa yang ada di 9 propinsi (370 MA penerima bantuan sarana laboratorium IPA dan 90 penerima bantuan sarana laboratorium bahasa), diperoleh jumlah MA sasaran sebanyak $214 \mathrm{MA}$ (171 MA penerima bantuan sarana laboratorium IPA dan 43 MA penerima bantuan sarana laboratorium Bahasa). 


\section{SLOVIN}

\begin{tabular}{ccc}
$\mathrm{N}$ & 460 & 460 \\
$\mathrm{n}$ & $\mathbf{-}+\mathrm{Ne}^{2}$ & \multicolumn{3}{c}{$1+(460 \times 0,0025)$} & 2,15
\end{tabular}

171 untuk laboratorium IPA dan 43 untuk laboratorium Bahasa.

$\mathrm{n}=$ ukuran sampel

$\mathrm{e}=$ nilai kritis (batas ketelitian / margin of error (moe)

$\mathrm{N}=$ besaran populasi

Responden penelitian sebanyak 7 orang ( 3 orang guru IPA (kimia, fisika, biologi), 1 orang guru bahasa dan 2 orang tenaga laboran IPA dan bahasa serta 1 orang kamad). Jumlah 951 orang (513 orang guru IPA (171 x 3), 43 orang guru bahasa, 214 orang tenaga laboran, $181 \mathrm{ka}-$ mad). Penarikan sampel dilakukan menggunakan teknik multistage random sampling.

Pengumpulan data dilakukan menggunakan instrumen/alat pengumpul data berupa kuesioner, cheklis data, studi dokumen dan wawancara. Penyebaran kuesioner dilakukan untuk menjaring data kuantitatip. Sedangkan cheklis data untuk mengecek jenis sarana yang pernah diterima dan kondisi sarana tersebut saat ini. Sementara studi dokumen dilakukan untuk melihat beberapa dokumen pendukung untuk memperdalam analisis. Sedangkan wawancara terhadap seluruh responden dilakukan untuk melengkapi data kuantitatif yang hasilnya untuk mempertajam terhadap analisis data kuantitatif. Analisis data dalam penelitian ini dilakukan dengan menggunakan teknik deskriptif statistik, yang hasilnya disajikan dalam bentuk tabel maupun grafik.

\section{HASIL DAN PEMBAHASAN}

\section{Deskripsi Data MA Sasaran}

Penelitian ini semula akan dilakukan di 214 MA yang terdiri dari 171 MA penerima bantuan laboratorium IPA dan 43 MA peneri- ma bantuan laboratorium Bahasa atau $181 \mathrm{MA}$ (133 penerima bantuan laboratorium IPA, 15 MA penerima bantuan laboratorium Bahasa, 33 MA penerima bantuan laboratorium IPA dan bahasa). Namun karena adanya ketidaktepatan data pemberian bantuan (4 sekolah yang terdata menerima bantuan laboratorium IPA, ternyata tidak pernah menerima bantuan tersebut dan 5 sekolah yang tercatat sebagai penerima bantuan laboratorium IPA tapi justru menerima bantuan laboratorium bahasa), sehingga penelitian hanya dilakukan di $210 \mathrm{MA}$ (162 MA penerima bantuan laboratorium IPA dan 48 MA penerima bantuan laboratorium Bahasa) atau 177 MA (129 penerima bantuan laboratorium IPA, 15 MA penerima bantuan laboratorium Bahasa, 33 MA penerima bantuan laboratorium IPA dan bahasa). Adapun jumlah responden per-madrasah sebanyak 7 orang terdiri dari kamad; guru IPA (fisika, kimia, biologi), guru bahasa, laboran IPA dan Bahasa. Dengan demikian, dari 177 MA, diperoleh responden sebanyak 921 orang yang terdiri dari 486 orang pendidik IPA (162 x 3), 48 orang pendidik bahasa, 210 orang tenaga laboran dan 177 orang kepala MA.

Terkait dengan kepemilikan sarana laboratorium khususnya gedung laboratorium, kenyataan di lapangan menunjukkan bahwa belum seluruh MA memiliki gedung laboratorium baik laboratorium IPA maupun bahasa. Penelitian yang yang mengkaji tentang kepemilikan gedung, kondisi/kelayakan gedung dan pemanfaatan gedung laboratorium, hasilnya menunjukkan bahwa dari 162 MA sasaran penelitian yang memperoleh bantuan sarana laboratorium IPA, baru sekitar 79,6.\% MA yang telah memiliki gedung laboratorium IPA, sehingga masih sekitar 20,4\% MA belum memiliki gedung laboratorium IPA. Perlu diketahui bahwa dari sejumlah MA yang telah memiliki gedung laboratorium tersebut, ternyata sebagian besar kondisinya belum memenuhi persyaratan, karena dari 79,6\% MA yang telah memiliki gedung laboratorium IPA, hanya sekitar $36 \%$ MA yang memiliki gedung laboratorium IPA dalam kondisi layak dan memenuhi 
standar, sedangkan sisanya sekitar 43,6 \% MA memiliki gedung laboratorium IPA dalam kondisi kurang layak/belum memenuhi standar. Indikator tidak/belum terpenuhinya standar kelayakan gedung laboratorium tersebut dapat dilihat dari segi ukuran/luas bangunan gedung yang rata-rata kurang memadahi (kurang luas/ sempit, kondisi bangunan gedung sudah mulai rapuh, model bangunan yang tidak diseting layaknya laboratorium, minim kelengkapan atau sarana laboratorium dsb). Disamping itu, masih banyak juga MA yang hanya memanfaatkan ruang kelas/ruang tertentu yang difungsikan sebagai laboratorium IPA, bahkan beberapa diantaranya hanya menggunakan ruangan yang sempit atau menumpang di perpustakaan.

Kondisi yang tidak jauh berbeda terjadi pada kepemilikan gedung laboratorium bahasa. Dari 48 MA sasaran penelitian yang memperoleh bantuan sarana laboratorium bahasa, ternyata masih ada sekitar 16,7 \% MA yang belum memiliki gedung laboratorium, sehingga hanya sekitar 83,3 \% MA memiliki gedung laboratorium bahasa. Dilihat dari kelayakannya, baru sekitar 45,8 \% MA yang memiliki gedung laboratorium dalam kondisi layak dan 22,8 \% memiliki gedung laboratorium dalam kondisi cukup layak, sedangkan 14,7 \% MA memiliki gedung laboratorium dengan kondisi kurang layak atau bahkan sangat kurang layak dengan indikator sebagaimana diuraikan di atas.

Jumlah MA yang tidak/belum memiliki gedung laboratorium IPA ini sebanding/hampir sama dengan jumlah MA yang tidak memiliki jurusan IPA. Dari 162 MA yang menerima bantuan sarana laboratorium IPA, hanya 71 MA yang memiliki jurusan IPA dan 91 MA tidak memiliki jurusan IPA. Tidak adanya jurusan IPA ini otomatis MA yang bersangkutan juga tidak memiliki gedung laboratorium IPA. Menurut sebagian kepala MA, keberadaan laboratorium IPA bagi MA yang tidak memiliki jurusan IPA dianggap belum terlalu penting, karena pembelajaran IPA hanya diberikan selama satu semester saja dan materi pelajaran IPA yang diberikannyapun masih merupakan materi dasar yang dalam pelaksanaan pembelajarannya belum membutuhkan bantuan sarana laboratorium IPA.

Temuan penelitian ini memberikan gambaran, kondisi kepemilikan gedung laboratorium IPA bagi MA ternyata tidak hanya kurang dari segi jumlah, tetapi juga dari segi kualitas. Sedangkan kepemilikan gedung laboratorium bahasa, dilihat dari kondisi dan kelayakannya sedikit lebih baik. Dari sekitar 83,3\% MA yang telah memiliki gedung laboratorium bahasa, sekitar $45,8 \%$ MA telah memiliki laboratorium bahasa dalam kondisi kelayakan di atas $66 \%$. Sedangkan dilihat dari pemanfaatannya, pemanfaatan laboratorium bahasa juga terlihat sedikit lebih baik dibanding pemanfaatan laboratorium IPA. Dari 83,3\% MA yang memiliki laboratorium bahasa, telah dimanfaatkan untuk kegiatan pembelajaran praktek bahasa sebanyak 1-4 kali/hari, 4-8 kali/minggu dan 8-15 kali/bulan. Sedangkan dari 79,6\% MA yang memiliki laboratorium IPA, rata-rata telah dimanfaatkan untuk kegiatan pembelajaran praktikum IPA sebanyak 1-2 kali/hari, 2-3 kali/minggu dan 3-6 kali/bulan.

Terkait dengan kepemilikan sarana berupa alat dan bahan laboratorium IPA, kondisinya tidak jauh berbeda dengan kepemilikan gedung. Penelitian yang dilakukan terhadap sarana laboratorium IPA yang meliputi perabot, peralatan dan bahan praktikum serta terhadap sarana laboratorium bahasa yang meliputi perabot dan peralatan laboratorium, dengan mengkaji kondisi, kelengkapan dan pemanfaatannya. Kondisi kepemilikan sarana ini tidak jauh berbeda dengan kondisi kepemilikannya, hasilnya menunjukkan bahwa dari 162 MA yang memperoleh bantuan sarana laboratorium IPA, hanya sekitar 65,3.\% MA memiliki perabot dalam kondisi baik dan 39\% MA memiliki kelengkapan perabot cukup baik. Sedangkan dari 48 MA yang memperoleh bantuan sarana laboratorium bahasa, hanya sekitar 60\% MA yang memiliki perabot laboratorium bahasa dalam kondisi baik dan sekitar 37,1 \% MA yang memiliki kelengkapan perabot juga dalam kondisi baik. Begitu juga pada aspek pemanfaatan perabot, baru sekitar 66,9\% MA 
yang mampu melakukan pemanfaatan perabot laboratorium IPA dan sekitar 72,9\% MA mampu memanfaatkan perabot laboratorium bahasa dengan baik.

Kurang maksimalnya kelengkapan laboratorium ini juga terlihat dari kepemilikan peralatan dan bahan praktikum. Untuk laboratorium IPA, baru sekitar 68,6\% MA yang memiliki peralatan laboratorium IPA dalam kondisi baik, sedangkan untuk laboratorium bahasa baru sekitar 46,6\% MA yang memiliki peralatan dalam kondisi baik. Begitu juga dalam pemanfaatannya, baru sekitar 63,7\% MA yang mampu memanfaatkan peralatan laboratorium IPA tersebut dengan baik dan sekitar 75,3\% MA mampu memanfaatkan peralatan laboratorium bahasa dengan baik. Terkait dengan kepemilikan bahan, kondisinya tidak jauh berbeda bahkan sedikit lebih buruk, karena hanya 58,4\% MA yang memiliki bahan praktikum dalam kondisi baik dan sekitar 66,1\% MA yang mampu memanfaatkan bahan laboratorium tersebut untuk kegiatan praktikum dengan baik.

Secara umum, temuan hasil penelitian tersebut memperlihatkan bahwa dilihat dari kondisi dan kelengkapannya, keberadaan sarana laboratorium baik laboratorium IPA maupun bahasa terlihat kurang maksimal, namun kondisi kelengkapan sarana laboratorium IPA sedikit lebih baik dibanding dengan sarana laboratorium bahasa. Sedangkan dilihat dari pemanfaatannya, terjadi kondisi yang sebaliknya, karena pemanfaatan laboratorium bahasa lebih baik dibanding dengan pemanfaatan laboratorium IPA. Membaiknya pemanfaatan laboratorium bahasa ini karena dukungan SDM pada laboratorium bahasa lebih memadahi baik secara kualitas maupun kuantitas dibanding dengan laboratorium IPA, sehingga pelaksanaan pembelajaran pada laboratorium bahasa khususnya pembelajaran praktek juga terlaksana dengan lebih baik.

\section{Deskripsi Pemanfaatan Sarana Laboratorium IPA dan Bahasa}

Penelitian terhadap pemanfaatan sarana laboratorium IPA dan bahasa di MA, di- lakukan melalui tiga indikator pemanfaatan yaitu proses pemanfaatan, cara pemanfaatan dan kegiatan pemanfaatan. Sedangkan untuk mengetahui kendala yang dihadapi dalam pemanfaatan sarana laboratorium IPA dan bahasa, dilakukan dengan melihat empat indicator yaitu ketersediaan sarana prasarana; ketersediaan pendidik dan tendik; ketersediaan peserta didik dan ketersedaan pendanaan.

\section{Proses pemanfaatan}

Proses pemanfaatan sarana laboratorium IPA dan bahasa adalah tahapan-tahapan yang dilakukan dalam pemanfaatan laboratorium IPA dan bahasa yang meliputi persiapan, pelaksanaan dan evaluasi/penilaian.

\section{Persiapan}

Persiapan dalam pemanafaatan laboratorium adalah kegiatan-kegiatan yang dilakukan sebelum melaksanakan pemanfaatan laboratorium (kegiatan sebelum praktikum dilakukan). Beberapa kegiatan yang dilakukan dalam persiapan antara lain menyusun jadwal praktikum, menyiapkan peralatan dan bahan praktikum, menjelaskan materi yang akan dipraktekkan, menjelaskan tujuan praktikum, mengenalkan peralatan dan bahan praktikum serta fungsinya, menyusun kelompok kerja, menyusun rancangan pembelajaran praktikum, menyediakan lembar kerja, mengatur meja dan kursi, mengatur pencahayaan dan mengatur suhu udara. Dari beberapa kegiatan persiapan tersebut, sebagian besar MA telah melakukan kegiatan persiapan dengan baik, karena sekitar $65,8 \%$ guru IPA telah melakukan persiapan secara rutin sebelum melakukan kegiatan praktikum IPA dan sekitar 77,5\% guru bahasa juga telah melakukan persiapan secara rutin sebelum melaksanakan kegiatan praktikum. Hasil ini sekaligus memperlihatkan bahwa persiapan yang dilakukan guru bahasa terlihat lebih baik dibandingkan dengan persiapan guru IPA.

Membaiknya persiapan yang dilakukan guru bahasa ini disebabkan karena pengua- 
saan guru bahasa terhadap materi yang akan diajarkan dan penguasaan terhadap sarana laboratorium, lebih baik dibandingkan guru IPA. Disamping itu, penguasaan terhadap pelaksanaan pembelajaran praktikum juga lebih baik. Umumnya guru bahasa memiliki kualifikasi pendidikan yang memadahi, kompetensi yang juga memadahi dan tidak mismatch. Sementara guru IPA di MA masih banyak yang belum memenuhi kualifikasi pendidikan sesuai SNP (S1), kompetensi juga kurang maksimal dan masih banyak yang mismatch. Sebagai contoh, guru mata pelajaran IPA (kimia, fisika, biologi) di MA Banu Hasyim dan MA Tanada di Sidoarjo, hanya diajarkan oleh seorang guru yang kurang menguasai seluruh materi pelajaran IPA, karena hanya memiliki satu guru IPA. Contoh lainnya, di MA Al-Hasaniyah Tangerang, karena tidak memiliki guru IPA, sehingga guru PAI yang biasa mengajar Qur'an Hadis, dalam kenyataan juga mengajar IPA.

Kenyataan seperti ini masih banyak dijumpai di beberapa MA khususnya MA swasta yang masih kekurangan SDM khususnya guru bidang studi tertentu semisal IPA. Sementara keberadaan guru bahasa, umumnya madrasah memilikinya minimal tiga orang guru seperti guru bahasa Indonesia, Arab dan Inggris. Beberapa MA yang mengajarkan lebih dari tiga bahasa bahkan sudah ada yang memiliki guru bahasa di luar yang tiga bahasa sebagaimana disebutkan seperti bahasa jepang, bahasa mandarin, bahasa Jerman dsb.

\section{Pelaksanaan}

Pelaksanaan pemanfaatan laboratorium adalah kegiatan pembelajaran dilakukan dengan memanfaatkan laboratorium atau kegiatan pembelajaran praktikum dengan memanfaatan sarana laboratorium. Beberapa kegiatan yang dilakukan pendidik dalam pelaksanaan pembelajaran praktikum antara lain membantu peserta didik menggunakan alat dan bahan; mendemonstrasikan penggunaan alat dan bahan; menyediakan pedoman; menggunakan perangkat laboratorium untuk praktek; membimbing peserta didik melakukan (percobaan/eksperimen, pengujian/pembuktian teori, penelitian dsb); disply/pameran; memberi tugas praktikum pada peserta didik, melaksanakan praktikum; memonitor jalannya kegiatan praktikum. Dari beberapa kegiatan tersebut umumnya MA yang menjadi sasaran penelitian telah melaksanakan pemanfaatan laboratorium untuk kegiatan praktikum dengan cukup baik meskipun belum maksimal, karena baru sekitar 66,2 \% MA yang telah melaksanakan pembelajaran praktikum IPA secara rutin dan sekitar 71,8 \% MA yang telah melaksanakan pembelajaran praktikum bahasa secara rutin.

Hasil tersebut memperlihatkan bahwa pelaksanaan pembelajaran praktikum bahasa juga terlihat lebih baik dibanding pelaksanaan pembelajaran praktikum IPA. Ini artinya bahwa pendidik bahasa yang melaksanakan pembelajaran praktikum bahasa persentasenya lebih tinggi dibandingkan dengan pendidik IPA yang melaksanakan pembelajaran praktikum IPA. Membaiknya pelaksanaan pembelajaran praktikum bahasa ini antara lain didukung Oleh: keberadaan pendidik bidang studi bahasa lebih memadahi dibanding pendidik bidang studi IPA baik dari segi kuantitas (jumlah pendidik) maupun kualitas (kualifikasi dan kompetensinya), seperti pendidikan S1 dengan bidang studi seauai dengan mata pelajaran yang diajar; Kepemilikan gedung laboratorium bahasa beserta perlengkapannya lebih mencukupi bagi MA dibanding kepemilikan laboratorium IPA; Keberadaan laboran bahasa juga lebih memadahi (secara kualifikasi dan kompetensi) dibanding laboran IPA, dsb.

Sedangkan pemanfaatan laboratorium IPA untuk masing-masing mapel IPA (fisika, kimia dan biologi) persentasenya hampir sama, namun pembelajaran biologi terlihat lebih sering dilaksanakan ketimbang mapel lain. Dari pengolahan data yang diperoleh dari 921 orang responden, dapat dideskripsikan pemanfaatan laboratorium IPA dan bahasa sbb. 
Tabel 1. Pemanfaatan Masing-malsing Mapel IPA dan Mapel Bahasa

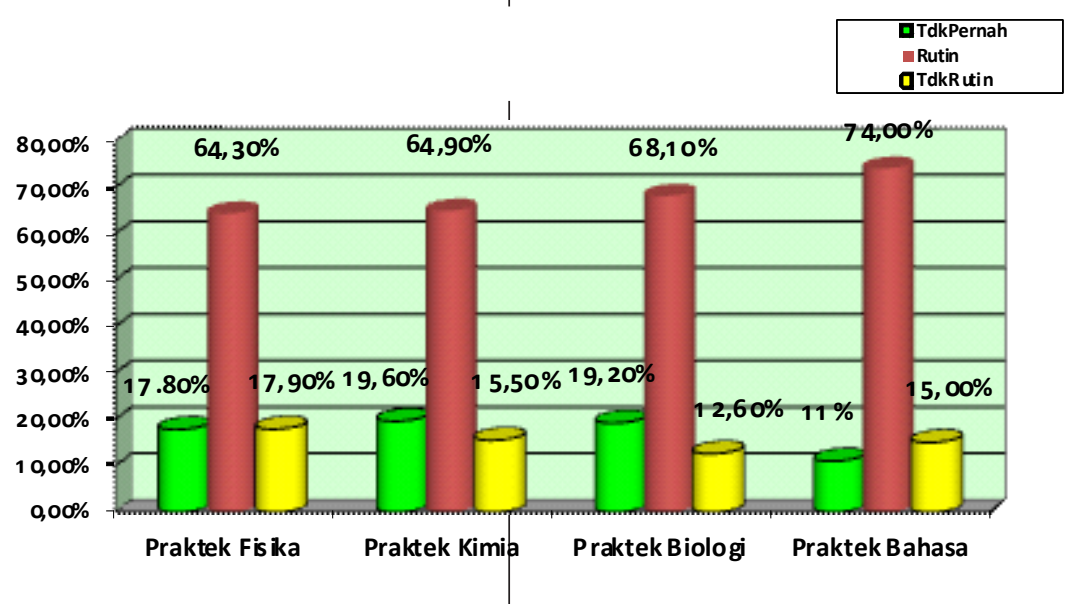

\section{Evaluasi}

Evaluasi/penilaian adalah pelaksanaan penilaian terhadap pembelajaran praktikum untuk melihat sejauhmana hasil yang dicapai dari pembelajaran praktikum dengan memanfaatkan laboratorium IPA dan bahasa. Beberapa kegiatan yang dilakukan dalam penilaian antara lain memberikan tugas kepada peserta didik untuk menyusun laporan hasil praktikum; memberikan pertanyaan secara lisan dan tertulis kepada peserta didik berkaitan dengan materi praktikum yang dilakukan setelah kegiatan selesai dan melakukan tes akhir semester untuk mengetahui tingkat pemahaman peserta didik terhadap materi yang telah dipraktekkan. Melalui berbagai kegiatan tersebut diketahui bahwa sekitar 65,3\% MA melakukan penilaian secara rutin untuk melihat capaian hasil pembelajaran praktikum IPA dan $71,6 \%$ melakukan penilaian secara rutin untuk melihat capaian hasil pembelajaran praktikum bahasa.

Hasil ini memberikan gambaran bahwa pada umumnya MA sasaran penelitian sebenarnya telah melakukan penilaian secara rutin setiap kali selesai melakukan kegiatan praktikum, meskipun dalam pelaksanaannya belum maksimal karena terkendala oleh berbagai hal antara lain keterbatasan SDM dan waktu pelaksanaan penilaian yang oleh sebagian pendidik dirasakan masih kurang longgar terutama untuk melakukan tes secara lisan terhadap peser- ta didik satu-persatu, waktu yang dijadwalkan terasa kurang memadahi.

Dari uraian tentang proses pemanfaatan laboratorium IPA dan bahasa yang dilakukan melalui tiga tahapan (persiapan, pelaksanaan dan penilaian), terlihat bahwa sekitar $65,8 \%$ MA telah melaksanakan proses memanfaatkan laboratorium IPA secara rutin dan sekitar 74\% MA juga telah melaksanakan proses pemanfaatan laboratorium bahasa secara rutin. Ini menunjukkan bahwa pada umumnya MA yang menjadi sasaran penelitian telah melaksanakan tahapan-tahapan dalam pemanfaatan laboratorium, baik laboratorium IPA maupun laboratorium bahasa pada kategori cukup baik, meskipun belum maksimal. Namun seberapa tingkat pemanfaatannya, antara MA satu dengan lainnya berbeda-beda. MA yang memiliki jurusan IPA terlihat lebih maksimal dalam memanfaatkan laboratorium IPA dibanding MA yang tidak memiliki jurusan IPA. Begitu juga MA yang memiliki jurusan bahasa terlihat lebih maksimal tingkat pemanfaatannya dibanding MA yang tidak memiliki jurusan bahasa. Keberadaan pendidik dan tenaga laboran juga sangat mempengaruhi tingkat pemanfaatan laboratorium. Bagi MA yang memiliki pendidik dan tenaga laboratorium memadahi baik secara kualifikasi maupun kompetensi, terlihat lebih maksimal dalam memanfaatkan laboratorium sebagai sarana penunjang pembelajaran. 


\section{Cara Pemanfaatan Sarana Laboratorium IPA dan Bahasa}

Cara pemanfaatan sarana laboratorium IPA dan bahasa disini maksudnya adalah teknis pemanfaatan sarana laboratorium IPA dan bahasa sebagai sarana penunjang pembelajaran. Untuk mengatahui cara pemanfaatan sarana laboratorium IPA dan bahasa dilakukan melalui beberapa indikator yaitu pemakaian, perawatan dan dukungan kebijakan.

\section{Pemakaian}

Pemakaian laboratorium baik laboratorium IPA maupun bahasa dilakukan dalam bentuk kegiatan pembelajaran praktikum IPA maupun bahasa. Dari 162 MA penerima bantuan sarana laboratorium IPA, sekitar 65,8 MA telah memakai sarana laboratorium IPA untuk kegiatan praktikum dan dari 48 MA yang memperoleh bantuan sarana laboratorium Bahasa, sekitar 74\% MA juga telah memakai sarana laboratorium bahasa untuk kegiatan praktikum bahasa.

\section{Perawatan}

Disamping memakai/memanfaatkan laboratorium melalui kegiatan pembelajaran praktikum, umumnya MA tersebut juga melakukan perawatan dengan baik. Ini terlihat dari jumlah MA yang melakukan perawatan sarana laboratorium IPA secara rutin persentasenya mencapai sekitar 87,6\% dan perawatan sarana laboratorium bahasa persentasenya mencapai sekitar $87 \%$. Kegiatan perawatan antara lain dengan melakukan pembersihan dan penyimpanan sarana laboratorium tersebut dengan baik. Perawatan merupakan bagian dari pemanfaatan laboratorium, karena dalam upaya menjaga keawetan sarana laboratorium agar dapat dimanfaatkan secara maksimal sebagai penunjang pembelajaran, maka keberadaannya harus dijaga dengan melakukan perawatan dengan baik yaitu dijaga kebersihannya, disimpan kembali setiap habis dipakai dan ditempatkan pada tempat penyimpanan yang baik (almari yang tertutup) agar tidak mudah kotor.

\section{Dukungan Kebijakan}

Hal lain yang dibutuhkan dalam rangka pemanfaatan sarana laboratorium adalah adanya dukungan kebijakan kepala MA tentang pembelajaran praktikum IPA dan bahasa dengan memanfaatkan sarana laboratorium. Adanya kebijakan ini penting, karena dikeluarkannya kebijakan berarti pembelajaran praktikum IPA dan bahasa memperoleh dukungan yang kuat dari kepala madrasah. Dengan adanya dukungan kebijakan berarti pula ada komitmen dari kepala madrasah untuk memberikan dukungan tidak hanya terbatas pada aspek legalitas, tetapi juga pada berbagai aspek lainnya seperti aspek sarana prasarana, ketenagaan, pendanaan dsb. Terkait dengan dukungan kebijakan ini, secara umum dapat dikatakan bahwa MA sasaran penelitian telah memperoleh dukungan kebijakan dari kepala madrasahnya masing-masing. Dari 177 MA penerima bantuan sarana laboratorium IPA dan bahasa, sekitar 60,5\% MA telah memiliki dukungan kebijakan tersebut (75\% berbentuk kebijakan tertulis dan $25 \%$ tidak tertulis).

Dari uraian hasil penelitian tentang cara pemanfaatan laboratorium IPA dan bahasa yang dilakukan melalui tiga cara yaitu pemakaian, perawatan dan dukungan kebijakan, dapat disimpulkan bahwa sekitar 71,5\% MA penerima bantuan laboratorium IPA dan 73,7 MA penerima bantuan laboratorium Bahasa telah memanfaatkan laboratorium IPA dan bahasa dengan cara yang cukup baik dan rutin, meskipun belum maksimal, karena masih banyak juga MA yang belum mampu memanfaatkan laboratorium IPA dan bahasa dengan cara yang cukup baik dan rutin. Untuk dapat memanfaatkan laboratorium dengan baik dan benar, perlu didukung oleh adanya SDM yang profesional yang memiliki kompetensi dan kualifikasi memadai. Oleh karena itu penyediaan SDM khususnya pendidik dan tenaga laboran baik IPA maupun bahasa merupakan hal penting yang harus diperhatikan MA, agar pelaksanaan pembelajaran dapat berjalan lancar. Keberadaan SDM khususnya pendidik (guru IPA dan bahasa) dan tenaga kependidikan (laboran IPA dan bahasa) di MA sasaran peneli- 
tian terlihat masih kurang memadahi baik secara kualitas dan kuantitas. Dari 162 MA yang memperoleh bantuan laboratorium IPA, hanya tersedia pendidik IPA sebanyak 597 orang, sehingga bila dirata-rata masing-masing MA hanya tersedia pendidik IPA sekitar 3 orang atau satu pendidik per-satu mata pelajaran (fisika, kimia, bilogi). Jumlah ini tentu kurang memadahi, karena sebagian besar MA memiliki jumlah rombel lebih dari dua rombel perjenjangnya bahkan ada yang memiliki sampai delapan rombel perjenjangnya. Hal yang sama terjadi pada pendidik bahasa, dari 48 MA yang memperoleh bantuan laboratorium bahasa, hanya tersedia pendidik bahasa sebanyak 124 orang. Bila dirata-rata, masing-masing MA hanya memiliki 2-3 orang pendidik bahasa. Bila sekolah mengajarkan lebih dari dua materi bahasa dan memiliki jumlah rombel yang cukup banyak, maka terjadi kekurangan jumlah guru bahasa di masing-masing MA. Sementara itu, dari 177 MA sasaran penelitian, masih ada $2 \%$ MA yang sama sekali belum memiliki guru IPA.

Disamping kekurangan pendidik, sebagian besar MA ternyata juga masih kekurangan tenaga laboran. Dari 162 MA yang memperoleh bantuan laboratorium IPA, hanya tersedia laboran IPA sebanyak 136 orang. Bila dirata-rata, setiap satu MA hanya memiliki laboran sekitar 0-1 orang. Ini artinya bahwa belum seluruh MA sasaran penelitian memiliki laboran IPA. Sedangkan untuk laboran bahasa, kondisinya sedikit berbeda. Dari 48 MA yang memperoleh bantuan laboratorium bahasa, tersedia laboran bahasa sebanyak 52 orang. Bila dirata-rata, masing-masing MA memiliki 1-2 orang laboran bahasa, namun MA yang memiliki 2 orang laboran bahasa jumlahnya lebih sedikit. Bila sekolah mengajarkan lebih dari dua materi pelajaran bahasa, maka masih terjadi kekurangan jumlah laboran bahasa di masing-masing MA untuk semua materi bahasa. Jumlah MA yang belum memiliki laboran cukup besar sekitar $45,8 \%$.

\section{Kegiatan Pemanfaatan Laboratorium IPA dan Bahasa}

Kegiatan pemanfaatan laboratorium IPA dan bahasa di MA dilakukan dalam bentuk pembelajaran praktikum IPA dan bahasa. Untuk mengetahui hal tersebut dapat dilihat dari jenis kegiatan, pelaksanaan kegiatan dan frekuensi kegiatan yang dilakukan. Untuk pembelajaran IPA, jenis kegiatannya meliputi pembelajaran praktikum fisika, kimia, bilogi dan untuk pembelajaran bahasa, jenis kegiatannya berupa pembelajaran praktikum bahasa untuk semua bahasa yang diajarkan di masing-masing MA. Namun karena jenis bahasa yang diajarkan berbeda-beda, maka tidak disebutkan satu persatu jenis bahasanya.

Dari 162 MA penerima bantuan sarana laboratorium IPA, sebanyak 106 MA $(65,8 \%)$ melaksanakan pembelajaran praktikum IPA (fisika, kimia dan biologi). Jumlah MA yang melakukan kegiatan praktikum fisika secara rutin sebanyak 104 MA (64,3\%); yang melakukan secara tidak rutin sebanyak 29 MA (17,9 \%) dan yang tidak melaksanakan sebanyak $27 \mathrm{MA}$ (17,8\%), dengan jumlah rata-rata siswa perkegiatan sebanyak 30 orang; jumlah rata-rata rombel sebanyak 2 rombel perkegiatan dan rerata pelaksanaan kegiatan perminggunya 3 kegiatan. Jumlah MA yang melakukan kegiatan praktikum kimia secara rutin sebanyak $105 \mathrm{MA}$ (64,9\%); yang melaksanakan secara tidak rutin sebanyak 25 MA $(15,5 \%)$ dan yang tidak melaksanakan sebanyak 32 MA $(19,6)$, dengan jumlah rata-rata siswa perkegiatan 34 orang; jumlah rata-rata rombel sebanyak 2 rombel dan rata-rata frekuensi kegiatan perminggunya 3 kegiatan. Jumlah MA yang melakukan kegiatan praktikum biologi secara rutin sebanyak 110 MA (68,1\%); yang melaksanakan pembelajaran praktikum secara tidak rutin sebanyak $21 \mathrm{MA}$ $(12,6 \%)$ dan yang tidak melaksanakan sebanyak 31 MA (19,2\%), dengan jumlah rata-rata siswa perkegiatan 40 orang; jumlah rerata rombel 2-3 rombel perkegiatan dan rata-rata frekuensi kegiatan 3 kegiatan perminggu. Sedangkan jumlah MA yang melaksanakan pembelajaran praktikum bahasa secara rutin sebanyak $36 \mathrm{MA}$ 
(74\%/) dari $48 \mathrm{MA}$; yang melaksanakan secara tidak rutin sebanyak 7 MA (15\%) dan yang tidak melaksanakan sebanyak 5 MA (11\%), dengan jumlah rata-rata siswa perkegiatan 34 orang dan jumlah rata-rata rombel sebanyak 1-2 rombel perkegiatan. Adapun rerata pelaksanaan kegiatan perminggunya 4 kegiatan.

Sedangkan frekuensi kegiatan yaitu jumlah kegiatan praktikum IPA dan bahasa yang dilaksanakan oleh masing-masing MA dengan rentang waktu tertentu misalnya setiap hari, setiap minggu, setiap bulan atau bahkan setiap semesternya. Untuk pembelajaran IPA, frekuensi kegiatan praktikum IPA yang dilakukan MA perharinya sebanyak 1-2 kali; perminggunya 2-3 kali dan perbulannya 3-6 kali pembelajaran praktikum. Sementara untuk pembelajaran praktikum bahasa sebanyak 1-4 kali perhari; 4-8 kali perminggu dan 8-16 kali perbulan.

\section{Kendala dan Solusi dalam Pemanfaatan Sarana Laboratorium}

Dalam pemanfaatan sarana laboratorium IPA dan bahasa, sebagian besar MA masih menemui beberapa kendala antara belum semua MA memiliki gedung laboratorium $(20,4 \%$ untuk laboratorium IPA dan $16,7 \%$ untuk laboratorium bahasa). Sedangkan beberapa MA yang telah memiliki gedung laboratorium sebagian besar kondisinya kurang layak (hanya sekitar $36 \%$ MA memiliki gedung laboratorium IPA dan $45,8 \%$ MA memiliki gedung laboratorium bahasa dengan kondisi layak di atas 66\%). Disamping itu sebagian besar MA tidak memiliki jurusan IPA dan jurusan bahasa, sehingga MA yang bersangkutan tidak memiliki laboratorium. Untuk mengatasi hal tersebut, sebagian MA memanfaatkan ruangan kelas atau ruang tertentu yang difungsikan sebagai laboratorium, meskipun dilihat dari kondisinya kurang memenuhi persayaratan sebagai laboratorium.

Kendala lainnya adalah jumlah pendidik; laboran IPA dan bahasa yang belum memadahi baik secara kualitas maupun kuantitas. Dari 162 MA yang memperoleh bantuan laboratorium IPA, hanya tersedia pendidik IPA sebanyak 597 orang, sehingga bila dirata-rata masing-masing MA hanya tersedia pendidik IPA sekitar 3 orang atau satu pendidik per-satu mata pelajaran (fisika, kimia, bilogi). Sementara ketersediaan pendidik bahasa hanya 124 orang. Bila dirata-rata, masing-masing MA hanya memiliki 2-3 orang pendidik bahasa Untuk laboran IPA tersedia sebanyak 136 orang dan untuk laboran bahasa tersedia sebanyak 52 orang. Bila dirata-rata, masing-masing MA hanya memiliki 0-1 laboran IPA dan 1-2 orang laboran bahasa. Dari sejumlah pendidik yang ada, sekitar $45 \%$ memiliki kompetensi kurang memadai. Sedangkan dari sejumlah tenaga laboran yang ada, sekitar 11,5 \% memiliki kompetensi kurang memadai. Kekuarangan jumlah pendidik dan tendik dari segu jumlah dan kualitas ini tentu akan sangat mempengaruhi kelancaran pelaksanaan pembelajaran IPA dan bahasa baik pada pembelajaran di kelas maupun n praktikum.

Ketersediaan pendanaan juga masih menjadi kendala di sebagian besar MA. Dilihat dari ketercukupannya, sebagian besar MA terlihat tidak memiliki sumber pendanaan yang mencukupi, karena tidak memiliki sumber pendanaan tetap dari pemerintah seperti halnya MA Negeri. Terbatasnya pendanaan ini menjadikan sebagian MA tidak mampu melaksaksanakan pembelajaran secara maksimal, baik pembelajaran di kelas, terlebih pembelajaran praktikum di laboratorium yang membutuhkan keberadaan bahan-bahan praktikum yang harganya cukup mahal. Sumber pendanaan terbesar MA adalah dari orangtua peserta didik, karena seluruh MA sasaran merupakan MA swasta. Sumber terbesar kedua dari APBN, kemudian dari APBD Propinsi dan terakhir dari APBD Kabupaten. Dari berbagai sumber tersebut ternyata hanya mencukupi kebutuhan MA rata-rata $50 \%$. Mengenai besaran sumber pendanaan, hampir semua MA tidak transparan memberikan penjelasan.

Pelaksanaan dan Kendala dalam Pemberian 


\section{Bantuan.}

Pelaksanaan pemberian bantuan sarana laboratorium IPA dan bahasa pada MA tahun 2010, ternyata juga menemui banyak masalah. Persoalan-persoalan yang muncul dalam pelaksanaan pemberian bantuan terlihat pada teknis pelaksanaan pemberian bantuan, sehingga bantuan yang diberikan lebih banyak tidak sesuai atau tidak tepat sasaran. Beberapa persoalan tersebut antara lain:

a. Dalam pelaksanaannya, pemberian bantuan tidak diawali dengan studi kelayakan untuk melihat tingkat kebutuhan MA terhadap laboratorium IPA, akibatnya pemberian bantuan banyak yang kurang tepat atau salah sasaran. MA yang tidak memiliki jurusan IPA dan menjadi sasaran pemberian bantuan jumlahnya cukup besar. Padahal MA yang tidak memiliki jurusan IPA, kebutuhan akan adanya laboratorium IPA tersebut tidak terlalu signifikan, karena pembelajaran IPA umunya hanya di berikan satu semester pada awal tahun ajaran dan materi pelajaran IPA yang diberikannyapun masih sebatas tingkat dasar serta lebih teoritik. Sehingga pemberian bantuan sarana laboratorium khususnya IPA untuk sebagian MA menjadi mubazir.

Kasus ini terjadi di beberapa MA salah satu contohnya MA Banu Hasyim di Sidoarjo dan beberapa MA lainnya yang kondisinya hampir sama. Ketika menerima bantuan, baik kepala maupun guru IPA yang hanya satu orang tersebut menjadi bingung, karena pelaksanaan pembelajaran IPA di MA nya tidak signifikan membutuhkan laboratorium IPA.

b. Pemberian bantuan juga tidak diawali dengan pemberitahuan terlebih dahulu, sehingga ketika bantuan datang kepala MA dan para pendidik IPA menjadi kaget dan bingung serta tidak tahu harus berbuat apa, karena MA penerima bantuan tersebut tidak memiliki jurusan IPA, tidak memiliki laboratorium IPA, tidak memiliki lahan dan biaya untuk membangun laboratorium IPA; tidak akan membuat laboratorium IPA dan membuka jurusan IPA. Dengan berbagai alasan tersebut, kepala dan pendidik MA mempertanyakan kepada peneliti apakah boleh jika peralatan tersebut di hibahkan ke madrasah lain agar tidak mubazir, karena MA tersebut tidak memiliki kemampuan memanfaatkan. Persoalan semacam ini juga terjadi di beberapa MA lain yang memiliki kriteria sama.

Contoh lain kurang tepat sasaran dalam pemberian bantuan ini misalnya kasus di Kota Tangerang, di data disebutkan MA Al-Mansuriyah Kota Tangerang, ternyata di madrasah tersebut tidak ada MA, yang ada MTs Al-Mansuriyah, sehingga bantuan ditolak. Kasus di Tanggamus Lampung, dalam data disebutkan MA Mambaul Ulum Margoyoso, ternyata MA tersebut sudah bubar karena tidak ada muridnya. Kasus di Semarang ada MA yang sudah bubar memperoleh bantuan. Kasus di Cepu, MA yang mengajukan permohonan tidak menerima bantuan, tetapi MA yang tidak mengajukan dan tidak punya jurusan IPA malah menerima bantuan. Kasus di Kab. Tangsel, seluruh MA penerima bantuan tidak punya jurusan IPA; di Sidoarjo dan Sulsel, hanya 3 MA yang memiliki jurusan IPA; di Sukabumi dari 12 MA hanya 4 MA yang punya jurusan IPA dll.

c. Pengiriman barang dilakukan tengah malam. Ini terjadi di sebagian besar MA. Contoh kasus Sidoarjo, bantuan datang waktu tengah malam dan didrop di salah satu MA sehingga merepotkan bagi MA lain. Pelaksanaan yang demikian menimbulkan dugaan adanya kecurangan yang dilakukan perusahaan jasa pengiriman, untuk mengakali agar pihak penerima barang mau menandatangai berkas pengiriman tanpa melakukan pengecekan, karena waktu tengah malam, menjadikan penerima barang tidak teliti dan kurang hati-hati.

d. Pemberian bantuan juga tidak dibarengi dengan kehadiran tenaga instruktur yang 
berperan dalam memberikan penjelasan tentang penggunaan alat, sehingga banyak guru IPA yang gaptek (gagap teknologi) tidak mampu menggunakan dan memfungsikan peralatan laboratorium IPA dan bahasa yang diterima. Salah satu kasus terjadi di MA Nurul Huda, karena tidak mampu merangkai peralatan teleskop, sehingga peralatan tersebut tidak bisa dipakai dan ini juga terjadi pada MA lain di berbagai daerah.

e. Meskipun bantuan dimaksudkan sebagai upaya peningkatan mutu madrasah, namun karena pemberian bantuan tidak tepat sasaran, sehingga peningkatan mutu tidak tercapai, karena madrasah penerima bantuan bukan madrasah yang membutuhkan peralatan tersebut. Madrasah yang tidak memiliki jurusan IPA, umumnya lebih memilih jika diberikan bantuan lab. bahasa atau perangkat multimedia, namun kebutuhan tersebut justru tidak diberikan.

Dari berbagai persoalan tersebut terkesan bahwa pemberian bantuan ini sepertinya dilaksanakan secara asal-asalan (asal terealisir pelaksanaannya) tanpa menghiraukan tingkat kebermanfaatannya, apakah bantuan tersebut benar-benar bermanfaat bagi si penerima bantuan. Untuk program pemberian bantuan semacam ini, seharusnya terlebih dahulu dilakukan studi pendahuluan dalam bentuk studi kelayakan apakah pihak penerima bantuan layak diberikan bantuan tersebut. Untuk pemberian bantuan laboratorium IPA misalnya, kelayakan dapat dilihat dari beberapa aspek misalnya: a) MA ybs memiliki jurusan IPA (ini mutlak penting diperhatikan), karena dengan mengabaikan hal ini maka bantuan akan mubazir dan tidak manfaat, karena MA yang tidak memiliki jurusan IPA tentu tidak siginifikan membutuhkan keberadaan laboratorium IPA sebagai sarana penunjang pembelajaran; $b$ ) MA ybs telah memiliki laboratorium IPA atau minimal memiliki ruang yang difungsikan sebagai laboratorium IPA, sehingga peralatan laboratorium IPA yang diberikan dapat ditempatkan pada tempat yang baik dan dapat dimanfaatkan; c) MA ybs memiliki guru IPA memadai secara kuantitas (memiliki guru fisika, kimia, biologi) dengan jumlah dan kompetensi memadai; d) MA ybs memiliki laboran/teknisi yang bertugas merawat peralatan yang diberikan, sehingga bantuan yang diberikan dapat awet dipakai dan tidak cepat rusak; e) MA ybs memiliki program pembelajaran praktikum atau setidaknya memiliki rencana program pembelajaran praktikum meskipun belum terealisir karena terkendala ketiadaan peralatan.

Disamping dilakukan studi kelayakan, pemberian bantuan sebaiknya dibarengi dengan juknis yang jelas mencakup kriteria yang harus dipenuhi bagi MA penerima bantuan; teknis pelaksanaan pemberian bantuan dan persayaratan administrasi serta MOU pelaksanaan bantuan baik dengan kentor kemenag setampat maupun pihak pemenang tender pengiriman, yang harus menyertakan teknisi guna membantu para guru dalam memanfaatkan peralatan, agar bantuan yang diberikan cepat dapat dimanfaatkan sebagai sarana penunjang pembelajaran.

\section{P E N U T U P \\ Kesimpulan}

Penelitian ini hasilnya menunjukkan bahwa bantuan sarana laboratorium yang diberikan tersebut telah dimanfaatkan MA untuk menunjang kelancaran pelaksanaan pembelajaran, namun tingkat pemanfaatnnya belum mencapai kategori maksimal. Pemanfaatan tersebut dilakukan melalui tiga indikator yaitu proses, cara, kegiatan pemanfaatan.

Pada Indikator proses yang dilakukan melalui tiga tahap yaitu persiapan, pelaksanaan dan penilaian, hasil penelitian menunjukkan bahwa sekitar 65,8 \% MA penerima bantuan sarana laboratorium IPA dan sekitar $74 \%$ MA penerima bantuan sarana laboratorium Bahasa telah memanfaatkan laboratorium secara rutin. 
Pada Indikator cara pemanfaatan yang dilakukan dalam bentuk kegiatan pemakaian dan perawatan, hasil penelitian menunjukkan bahwa sekitar 65,8\% MA penerima bantuan sarana lab. IPA dan sekitar 74,1\% MA penerima bantuan sarana lab. Bahasa telah memakai/memanfaatkan bantun sarana laboratorium tersebut melalui kegiatan praktikum IPA dan bahasa; sekitar $87,6 \%$ MA penerima bantuan sarana lab. IPA dan sekitar $87 \%$ MA penerima bantuan sarana lab. Bahasa telah melakukan perawatan dengan baik. Dalam kegiatan memakai/ memanfaatkan bantuan sarana laboratorium tersebut, masing-masing MA memperoleh dukungan kebijakan dari kepala madrasah. Seki$\operatorname{tar} 61,1 \%$ MA penerima bantuan lab. IPA dan sekitar 60\% MA penerima bantuan lab. Bahasa memperoleh dukungan dari kepala MA.

Pada indikator kegiatan pemanfaatan yang dilihat melalui tiga aspek yaitu jenis kegiatan, frekuensi kegiatan dan jadwal praktikum, hasilnya menunjukkan bahwa sekitar $64,3 \%$ MA telah melaksanakan kegiatan praktikum fisika, 64,9\% melaksanakan kegiatan praktikum kimia, 68 \% MA melaksanakan kegiatan praktikum biologi dan $74 \%$ melaksanakan kegiatan praktikum bahasa. Adapun frekuensi kegiatannya untuk praktikum IPA (1-2 kali dalam sehari, 2-3 kali dalam seminggu, 3-6 kali dalam sebulan) dan untuk praktikum bahasa (1-4 kali dalam sehari, 4-8 kali dalam seminggu dan 8-15 kali dalam sebulan).

Dalam pemanfaatan laboratorium tersebut masih ditemui beberapa kendala antara lain ketersediaan SDM (guru dan laboran IPA dan bahasa) dan ketersediaan sarana prasarana laboratorium (gedung, alat dan bahan) yang juga kurang memadai. Begitu juga dalam pelaksanaan pemberian bantuan, masih ditmui kendala antara lain tidak dilakukan studi kelayakan, tidak ada pemberitahuan, tidak ada pengajuan proposal, tidak ada persyaratan bagi penerima bantuan dan tidak ada instruktur. Akibatnya pemberian bantuan banyak kurang tepat/salah sasaran.

\section{Saran-Saran}

Mengingat masih banyaknya kelemahan dalam pemberian bantuan dan pemanfaatannya, maka direkomendasikan kepada pemerintah dalam hal ini Kementerian Agama melalui Dirjen Pendis sbb:

a. Untuk memperbaiki kondisi MA penerima bantuan agar dapat memanfaatkan bantuan sarana lab. IPA dan bahasa yang telah diterima, antara lain dengan menambah jumlah guru dan laboran IPA dan bahasa di MA penerima baik melalui pengangkatan CPNS maupn guru honor.

b. Meningkatkan profesionalitas guru IPA dan bahasa melalui workshop, seminar maupun diklat mapel IPA dan bahasa.

c. Menyediakan fasilitas gedung laboratorium dengan mengalokasikan anggaran yang memadai

d. Menginventarisir ulang MA yang belum mendapatkan paket bantuan sarana lab IPA dan bahasa untuk selanjutnya dicarikan pemecahannya

e. Untuk pelaksanaan program serupa di masa mendatang, disarankan:

- diawali dengan studi pendahuluan untuk menentukan madrasah mana yang layak menerima bantuan agar tepat sasaran

- disyaratkan adanya pengajuan proposal oleh madrasah, sehingga madrasah penerima bantuan adalah madrasah yang benar-benar membutuhkan

- ada pemberitahuan terlebih dahulu ketika bantuan akan diberikan

- dilakukan pendataan yang akurat sehingga tidak salah sasaran

- Pemberian bantuan disertai dengan instruktur pendamping untuk membantu para guru dan laboran merangkai dan menggunakan sarana yang diberikan.

f. Bagi para pendidik, perlu diingat bahwa pembelajaran IPA tidak hanya menekankan hasil tetapi juga menekankan proses, de- 
ngan aspek-aspek yang hendak dicapai meliputi aspek pengetahuan, keterampilan dan sikap secara terpadu. Untuk itu disarankan agar dalam pembelajaran IPA lebih banyak memanfaatkan laboratorium dengan menerapkan pendekatan inquiry dan pendekatan keterampilan proses, disesuaikan dengan kondisi di lapangan.

g. Bagi kepala MA, disarankan agar lebih banyak memberi perhatian terhadap pemanfaatan sarana laboratorium di instansi pendidikan yang dipimpinnya dengan cara memotivasi dan memantau pemanfaatan laboratorium oleh para pendidik yang bersangkutan, mengalokasikan dana yang cukup untuk pengadaan bahan dan alat praktikum, mengefektifkan petugas laboran, dan memfungsikan ruang laboratorium sebagaimana mestinya. Sebaiknya dikeluarkan kebijakan yang mendukung pembelajaran praktikum.

\section{Ucapan Terima Kasih}

Tulisan ini merupakan hasil pengolahan data penelitian yang dilakukan di 9 propinsi yang pengumpulan datanya dilakukan oleh peneliti sebanyak 20 orang. Oleh karena itu penulis mengucapkan terima kasih kepada seluruh peneliti yang telah membantu dalam pengumpulan data penelitian ini.

\section{SUMBER BACAAN}

Arikunto, Suharsimi, 1987, Pengelolaan Materiil, Jakarta: Prima Karya.

Direktorat Jenderal Pendidikan Islam Kementerian Agama RI, 2010, Buku Statistik Pendidikan Islam Tahun 2010.

Departemen Agama, 2002, Panduan Teknis Pengelolaan Laboratorium Kimia, Jakarta: Dirjen Kelembagaan Agama Islam .

Pedoman Pendayagunaan Laboratorium dan Alat Pendidikan IPA, 1995, Jakarta: Direktorat Pendidkan Menengah Umum
Depdikbud, 1988, Pengelolaan laboratorium dan Manual Alat IPA, Jakarta: CV. Arga Karya.

Eriyanto, 2007, Teknik Sampling (Analisis Opini Publik), Yogyakarta: LKIS Pelangi Aksara.

Jay, M. Safritz, 1988, The Facts on File Dictionary of Education, New York: Facts on File.

Kertiasa, Nyoman, 2006, Laboratorium Sekolah dan Pengelolaannya, Jakarta: pudak Scientivic

Keputusan Dirjen Pendis Nomor DJ.I/744.A/2010, tertanggal 28 Oktober 2010, Tentang Penetapan Penerima Bantuan Alat Laboratorium IPA Terpadu MA.

Keputusan Dirjen Pendis Nomor DJ.I/1473.N/2011, tertanggal 28 Oktober 2010, Tentang Penetapan Penerima Bantuan Alat Laboratorium Bahasa Tahun Anggaran 2010.

Keputusan Dirjen Pendis Nomor DJ.I/731.A/2010, Tentang Penetapan Penerima Bantuan Alat Laboratorium IPA MTs Tahun Anggaran 2010.

Keputusan Dirjen Pendis Nomor DJ.I/737.B/2010, Tentang Penetapan Penerima Bantuan Pengadaan Peralatan Laboratorium IPA MA Tahun Anggaran 2010

Lubis dkk, Muhsin, 1993 Pengelolaan Laboratorium Ilmu Pengetahuan Alam, Jakarta: Universitas Terbuka.

Miarso, Yusuf Hadi, 1994, Definisi Teknologi Pendidikan: Satuan Tugas Definisi dan Teknologi AECT, Jakarta: CV. Rajawali.

Pusat Kurikulum, 2003, Kurikulum Berbasis Kompetensi, Jakarta: Balitbang Depdiknas.

Permendiknas No. 26 tahun 2008, Tentang Standar Tenaga Laboratorium Sekolah/ Madrasah, Tertanggal 11 Juni 2008.

Republik Indonesia, Permendiknas No. 40 Tahun 2008 Tentang "Standar Sarana dan Prasarana Untuk Sekolah Menengah Kejuruan/ Madrasah Aliyah Kejuruan (SMK/MAK)". 
Seels, Barbara dan Richy, Rita C., 1994, Teknologi Pembelajaran, Jakarta: Universitas negeri Jakarta Pres.

Sadiman, Arief F. dkk, 1990, Media Pendidikan: Pengertian Pengembangan dan Pemanfaatannya, Jakarta: CV. Rajawali

Subiyanto, 1990, Strategi Belajar Mengajar Ilmu Pengetahuan Alam/IPA, Malang: IKIP Malang.
Soekoro, Soewito, 1987, Kamus Pintar Ilmu Pengetahuan Alam/SAINS, (Jakarta: Citra Wacana Mitra pelajar.

Apis Indika dalam http://bioonline.wordpress. com/2011/06/07/pengertian-laboratorium/, tanggal 3 Januari 2012

Baim, http://baim87-bio.blogspot. com/2011/05/pemanfaatan-laboratorium -dalam-belajar.html, diakses tanggal 3 Januari 2012. 